Article

\title{
Impact and Effectiveness of Legislative Smoking Bans and Anti-Tobacco Media Campaigns in Reducing Smoking among Women in the US: A Systematic Review and Meta-Analysis
}

\author{
Yelena Bird ${ }^{1}$, Ladan Kashaniamin ${ }^{2}$, Chijioke Nwankwo ${ }^{3}$ and John Moraros ${ }^{4, *}$ \\ 1 Director iCAN Research Group, Brandon, MB R7A 0V6, Canada; yelenabird@gmail.com \\ 2 Department of Community Health and Epidemiology, University of Saskatchewan, Saskatoon, \\ SK S7N 2Z4, Canada; ladan.kashani@usask.ca \\ 3 School of Public Health, University of Saskatchewan, Saskatoon, SK S7N 2Z4, Canada; ckn313@mail.usask.ca \\ 4 Faculty of Health Studies, Brandon University, Brandon, MB R7A 6A9, Canada \\ * Correspondence: morarosj@brandonu.ca
}

Received: 19 November 2019; Accepted: 11 January 2020; Published: 16 January 2020

check for updates

\begin{abstract}
Background: The purpose of this study is to systematically review the literature addressing the effectiveness of legislative smoking bans and anti-tobacco media campaigns in reducing smoking among women. Methods: MEDLINE, PubMed, CINAHL, and ABI/INFORM were searched for studies published from 2005 onwards. Meta-analysis was conducted using a random effects model and subgroup analysis on pre-selected characteristics. Results: In total, 652 articles were identified, and five studies satisfied the inclusion criteria. The studies varied from school-based to workplace settings and had a total of 800,573 women participants, aged 12 to 64 years old. Three studies used legislative bans, one study used anti-tobacco campaigns and another one used both as their intervention. The overall pooled effect of the five studies yielded an odds ratio $(\mathrm{OR})=1.137$ (C.I. $=0.976-1.298$ and $\mathrm{I}^{2}=85.6 \%$ ). Subgroup analysis by intervention revealed a significant pooled estimate for studies using legislative smoking bans $\mathrm{OR}=1.280$ (C.I. $=1.172-1.389$ and $\mathrm{I}^{2}=0 \%$ ). Conclusion: Legislative smoking bans were found to be associated with a reduction in the smoking rates among women compared to anti-tobacco media campaigns. Further research in this area is needed.
\end{abstract}

Keywords: smoking; women; legislative smoking bans; anti-tobacco media campaigns

\section{Introduction}

The first report of the United States (US) Surgeon General's Advisory Committee on Smoking found that cigarette smoking is a probable cause of lung cancer and poses a serious risk of death and disease for women [1]. More than 50 years later, smoking is still the leading cause of premature death among women in the US and across the world [2,3]. Despite increased awareness of the harm caused by cigarette smoking, the effectiveness of global tobacco control initiatives has been questionable and the gains modest. The World Health Organization (WHO) predicts that cigarette smoking will continue to kill approximately eight million people a year, resulting in more than one billion deaths over the course of the 21st century [4].

Men continue to have higher smoking rates than women in the US and across the world but the gap has steadily decreased over the last couple of decades $[5,6]$. The narrowing of the gap suggests that women now share a much larger burden of smoking-related diseases, morbidities and mortalities than ever before. For instance, between 1960 and 1990, death rates from lung cancer among US women increased by more than 500\% [7]. Starting in the late 1980s, lung cancer surpassed breast cancer to 
become the leading cause of cancer death among women in the US [8]. Studies have shown the risk for chronic diseases and dying due to smoking to be considerably higher in women than men over the past 50 years [9-11].

Tobacco companies have increasingly used a gendered specific approach in their marketing campaigns to effectively target women. Many studies have shown that advertising campaigns by the tobacco industry seek to connect smoking to desirable women behaviours and attributes [12-14]. Behaviours are linked to the importance and value of smoking to women in creating fun-loving environments, strong social relationships, positive body image, weight control, independence, social status, sexual desirability and self-relaxation/medication [12]. Attributes such as cigarette size (i.e., long and slim), packaging (i.e., glitzy and sexy), and taste (i.e., light and flavourful) have been changed and designed to attract women. For instance, brands such as Vogue, Silk-Cut, and Virginia Slims have introduced attractive packaging styles like purse packs and a number of limited edition cigarette packs that have been heavily promoted by famous women celebrities and even fashion designers [14].

It is ironic that tobacco companies have linked smoking to women's independence/social status and well-being and yet cigarette smoking has had the opposite effect on their economic empowerment and physical health. Without empowerment and health, women cannot achieve equality and certainly cannot prosper. Research has shown that girls and women who smoke are more likely to be socioeconomically disadvantaged and/or marginalized [15-17]. Therefore, women are a top priority population for tobacco control and prevention efforts. The Framework Convention for Tobacco Control (FCTC) led to a multi-national treaty to help combat the global scourge of tobacco epidemic among a number of vulnerable populations including women [18]. The FCTC identified legislative bans and anti-tobacco media campaigns as important levers to help reduce smoking rates among women [18].

A systematic review by Hoffman et al. found that legislative bans and anti-tobacco media campaigns are effective tools in reducing smoking rates among countries that ratified the FCTC treaty [19]. Additionally, Bala et al. and De Kleijen et al. concluded that mass media campaigns can be effective strategies in smoking reduction and cessation efforts among adults [20,21]. However, there is a significant gap in the literature regarding the systematic assessment of this important topic, specifically among women. Therefore, the purpose of this study is to conduct a systematic review of the literature for quantitative evidence that determines the impact and effectiveness of legislative smoking bans and anti-tobacco media campaigns in reducing smoking among women in the US.

\section{Methods}

\subsection{Selection of Studies}

Identified studies were screened for eligibility by two reviewers. Articles were considered eligible for inclusion in the present study if they: (1) evaluated the effects of legislative smoking bans and/or anti-tobacco media campaigns among populations that included women 15 years old or older; (2) evaluated smoking status before and after the establishment of legislative smoking bans or anti-smoking media campaigns; (3) had a comparison group included in the study; (4) reported quantitative outcome measures specifically for women; and (5) were published in the English language in peer-reviewed journals since 2005, and available in full text.

\subsection{Search Strategy}

Search terms related to legislative smoking bans and anti-tobacco media campaigns were used to search four online databases including: (1) Medline; (2) PubMed; (3) CINAHL; and (4) ABI/INFORM. A grey literature search was also conducted on Google and on ProQuest Dissertations \& Thesis Global databases. The references of relevant articles were also carefully reviewed to identify possibly related studies. Search results were imported to separate Excel spreadsheets by using reference management 
software (Zotero, Corporation for Digital Scholarship, Vienna, Virginia, USA) and duplicate articles were removed.

\subsection{Data Extraction and Analysis}

Using Excel spreadsheets, characteristics of selected studies were extracted including author, publication year, type of study, number of women participants, type of intervention and effect estimates. Crude odds ratios and $95 \%$ confidence intervals were computed using the online MedCalc tool for studies that did not provide them but had cross-tabulated data [22]. Meta-analysis was conducted using a random effects model. The random-effects model was used to determine the pooled mean effect size because it enables comparisons between the statistical results arising from the different samples and methodology (measuring methods and units) found among the selected studies [23]. The primary outcome measure was the odds ratio (OR). OR calculations relied on study participant responses based on their smoking habits before and after establishment of legislative smoking bans or anti-smoking media campaigns. ORs and 95\% confidence intervals (CIs) were either extracted from the articles or calculated by the authors using the quantitative data provided in the studies.

Statistical analysis for heterogeneity was assessed using Higgins I-squared [24] and further explored with the use of subgroup analysis on predetermined characteristics such as the study design, type of intervention and type of outcome assessed. The robustness of the findings was assessed by determining the influence of each individual study on the overall pooled estimate using Tobias' method [25]. Publication bias was ascertained using a funnel plot and Egger's test. All analyses were carried out using Stata/IC version 13.1, College Station, TX: StataCorp LP, College Station, Texas, USA.

\section{Results}

\subsection{Article Identification}

In total, 652 articles were identified (636 from a database search, eight from the grey literature and eight using a snowball search). After removing duplicates, 640 articles underwent a two-step screening process. The first step included a review of all titles and abstracts for relevance. Following this step, 575 studies were excluded. The second step included a careful review of the remaining 65 full text articles. Following this step, only five studies [26-30] met the eligibility criteria and were included in the meta-analysis. The summary of our study selection is shown in a PRISMA diagram (Figure 1).

\subsection{Study Characteristics}

The total number of women participants was 800,573 . The age of the women ranged from 12 to 64 years old. All studies were based in the US. The studies varied from school-based [29] to workplace [28] settings. Out of the five studies included, only one [27] used a high-quality study design (i.e., quasi-experimental) with control groups. The other four studies [26,28-30] used a lower quality experimental design (i.e., cross-sectional) without control groups. Among the five studies eligible for inclusion, three $[27,28,30]$ used legislative bans, one used anti-tobacco campaigns [29] and another one used both [26] as their intervention. The study characteristics are presented in Table 1. 
PRISMA 2009 Flow Diagram

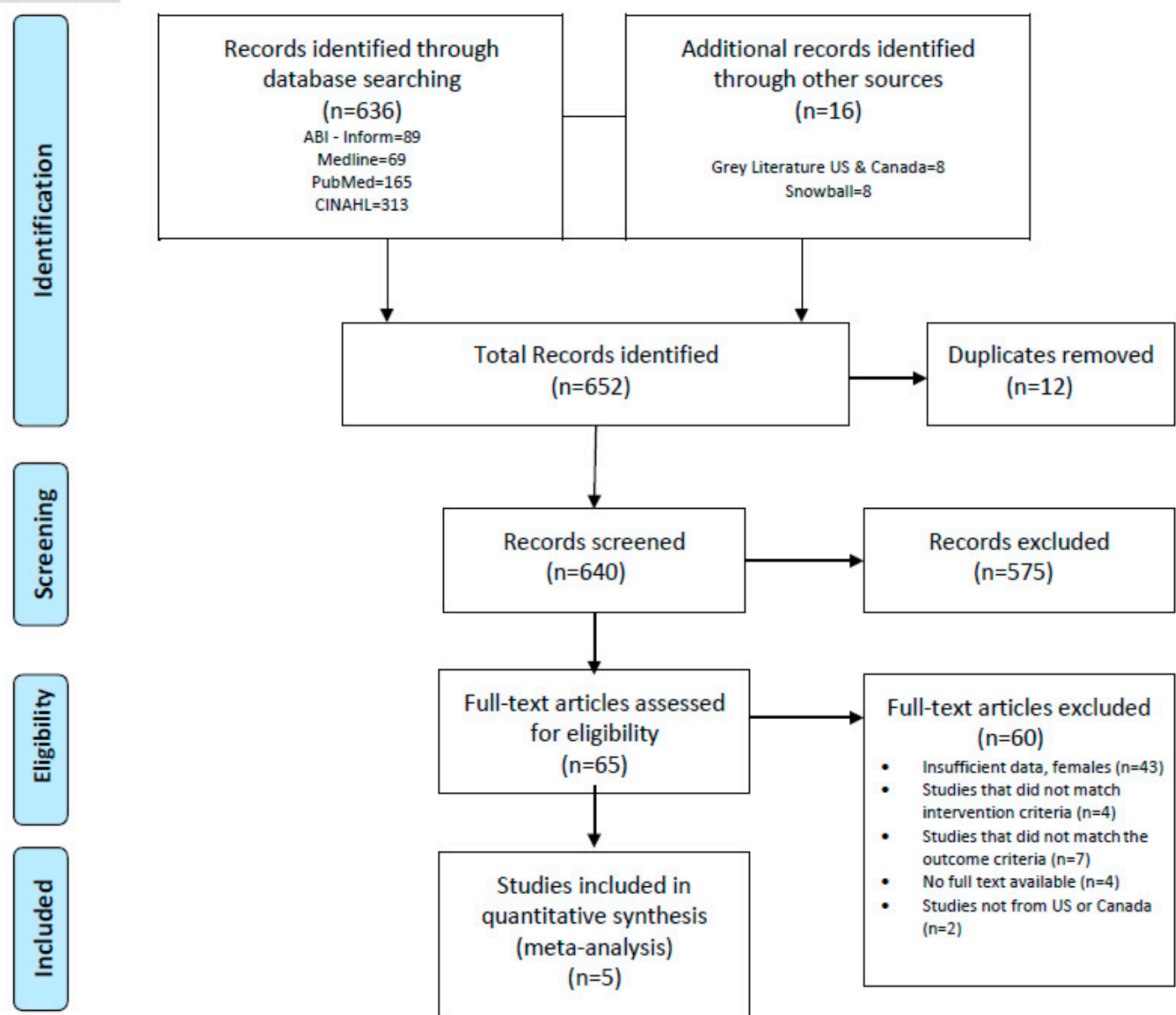

Figure 1. PRISMA diagram, study selection process. Preferred Reporting Items for Systematic Reviews and Meta-Analyses (PRISMA) flow diagram. 
Table 1. Study Characteristics.

\begin{tabular}{|c|c|c|c|c|c|c|c|c|c|c|c|}
\hline Year & Author & Purpose & $\begin{array}{l}\text { Study } \\
\text { Type }\end{array}$ & Data Source & $\begin{array}{l}\text { Number of } \\
\text { Females }\end{array}$ & $\begin{array}{c}\text { Age Range of } \\
\text { Females (years) }\end{array}$ & $\begin{array}{c}\text { Type of } \\
\text { Intervention }\end{array}$ & $\begin{array}{c}\text { Type of } \\
\text { Outcome }\end{array}$ & OR (CI) & Strengths & Limitations \\
\hline 2014 & Zablocki et al. & $\begin{array}{l}\text { To assess the association } \\
\text { of smoking ban policies } \\
\text { with smoking reduction } \\
\text { and quit attempts among } \\
\text { California smokers. }\end{array}$ & $\begin{array}{c}\text { Cross } \\
\text { sectional }\end{array}$ & $\begin{array}{l}2011 \text { California } \\
\text { longitudinal } \\
\text { smokers survey }\end{array}$ & 934 & $\geq 18$ & $\begin{array}{c}\text { Home smoking } \\
\text { ban, work place } \\
\text { smoking ban, } \\
\text { perceived } \\
\text { city/community } \\
\text { smoking ban }\end{array}$ & $\begin{array}{c}\text { Smoking } \\
\text { prevalence }\end{array}$ & $\begin{array}{c}\text { OR: } 1.1 \\
(0.5-2.3)\end{array}$ & $\begin{array}{l}\text { Participants are randomly } \\
\text { selected, first study to } \\
\text { examine the association of } \\
\text { perceived city/town } \\
\text { smoking bans at outdoor } \\
\text { locations with } \\
\text { smoking behaviors. }\end{array}$ & $\begin{array}{l}\text { Intervention \& outcome } \\
\text { data were assessed using } \\
\text { self-reported data. Only } \\
50 \% \text { of the sample } \\
\text { participated in } \\
\text { the follow-up. }\end{array}$ \\
\hline 2012 & Page et al. & $\begin{array}{l}\text { To examine the effect of a } \\
\text { citywide smoking ban in } \\
\text { comparison to a } \\
\text { municipality with no } \\
\text { smoking ban in Colorado } \\
\text { on maternal smoking } \\
\text { outcomes and subsequent } \\
\text { fetal birth outcomes. }\end{array}$ & $\begin{array}{c}\text { Natural } \\
\text { experiment }\end{array}$ & $\begin{array}{l}\text { State of Colorado } \\
\text { Department of } \\
\text { Health, Colorado } \\
\text { Birth Registry, and } \\
\text { the Infant Mortality } \\
\text { Registry data }\end{array}$ & 19,769 & $\begin{array}{c}\text { All ages } \\
\text { were included. }\end{array}$ & $\begin{array}{c}\text { Legislative } \\
\text { smoking ban }\end{array}$ & $\begin{array}{c}\text { Smoking } \\
\text { prevalence }\end{array}$ & $\begin{array}{c}\text { OR: } 1.26 \\
(1.13-1.40)\end{array}$ & $\begin{array}{l}\text { First evidence in regard to } \\
\text { improvement of fetal } \\
\text { outcomes and preterm } \\
\text { birth as a result of } \\
\text { smoking ban in the } \\
\text { United States. Including a } \\
\text { comparison group with } \\
\text { same demographics in } \\
\text { the study. }\end{array}$ & $\begin{array}{l}\text { Self-reported data is used, } \\
\text { Mothers' exposure to } \\
\text { second-hand smoke was } \\
\text { not measured directly. } \\
\text { Paternal smoking history } \\
\text { was not included in the } \\
\text { data to estimate SHS. } \\
\text { Maternal self-report is } \\
\text { probably under-reported } \\
\text { due to social stigma } \\
\text { related to smoking during } \\
\text { pregnancy. Mothers } \\
\text { reported lifetime smoking, } \\
\text { not in the time period } \\
\text { close to the pregnancy. }\end{array}$ \\
\hline 2011 & Rose et al. & $\begin{array}{l}\text { To assess the prevalence } \\
\text { of work place and home } \\
\text { smoking bans and their } \\
\text { associations with } \\
\text { intention to quit, quit } \\
\text { attempts, and 3-month } \\
\text { sustained abstinence } \\
\text { among employed females. }\end{array}$ & $\begin{array}{c}\text { Cross } \\
\text { sectional }\end{array}$ & $\begin{array}{l}\text { Cross-sectional data } \\
\text { from the 2006/2007 } \\
\text { Tobacco Use } \\
\text { Supplement to } \\
\text { the Current } \\
\text { Population Survey }\end{array}$ & 7610 & $18-64$ & $\begin{array}{l}\text { Home and } \\
\text { work place } \\
\text { smoking bans }\end{array}$ & $\begin{array}{c}\text { Smoking } \\
\text { prevalence }\end{array}$ & $\begin{array}{l}\text { AOR: } 1.29 \\
(0.83-2.00)\end{array}$ & $\begin{array}{l}\text { First study to examine the } \\
\text { association of full } \\
\text { smoking bans (at home } \\
\text { and work place) with } \\
\text { smoking behaviors among } \\
\text { employed female smokers. } \\
\text { Effect of complete work } \\
\text { and home ban was } \\
\text { analysed in addition to } \\
\text { their separate effects. }\end{array}$ & $\begin{array}{l}\text { Employed indoor females } \\
\text { were included in this } \\
\text { study. Therefore these } \\
\text { data may not be } \\
\text { generalizable to all } \\
\text { females. The data } \\
\text { reported are } \\
\text { cross-sectional and do not } \\
\text { allow for causal } \\
\text { associations. Self-reported } \\
\text { data is used. Detailed } \\
\text { information such as } \\
\text { coworkers and spouse } \\
\text { smoking and quitting } \\
\text { were not collected in the } \\
\text { dataset which they may } \\
\text { be influential on } \\
\text { smoking behaviour. }\end{array}$ \\
\hline
\end{tabular}


Table 1. Cont.

\begin{tabular}{|c|c|c|c|c|c|c|c|c|c|c|c|}
\hline Year & Author & Purpose & $\begin{array}{l}\text { Study } \\
\text { Type }\end{array}$ & Data Source & $\begin{array}{c}\text { Number of } \\
\text { Females }\end{array}$ & $\begin{array}{c}\text { Age Range of } \\
\text { Females (years) }\end{array}$ & $\begin{array}{c}\text { Type of } \\
\text { Intervention }\end{array}$ & $\begin{array}{c}\text { Type of } \\
\text { Outcome }\end{array}$ & OR (CI) & Strengths & Limitations \\
\hline 2009 & Levy et al. & $\begin{array}{l}\text { To examine the association } \\
\text { between tobacco control } \\
\text { policies (clean air laws } \\
\text { and media campaigns) } \\
\text { with smoking prevalence. }\end{array}$ & $\begin{array}{c}\text { Cross } \\
\text { sectional }\end{array}$ & $\begin{array}{l}\text { Tobacco Use } \\
\text { Supplement to the } \\
\text { Current Population } \\
\text { Survey 1992-2002 }\end{array}$ & $\begin{array}{l}\text { Total } \\
\text { sample: } \\
707,720 \\
\text { (Number of } \\
\text { females not } \\
\text { mentioned) }\end{array}$ & $\geq 18$ & $\begin{array}{c}\text { Antismoking } \\
\text { policies, } \\
\text { Anti-smoking } \\
\text { media } \\
\text { campaigns }\end{array}$ & $\begin{array}{l}\text { Smoking } \\
\text { prevalence }\end{array}$ & $\begin{array}{c}\text { OR (Clean } \\
\text { air): } 1.33 \\
(1.15-1.54) \\
\text { OR } \\
\text { (Media): } \\
1.07 \\
(0.99-1.16)\end{array}$ & $\begin{array}{l}\text { Examining the effect of } \\
\text { different tobacco control } \\
\text { policies on smoking } \\
\text { prevalence. A dataset } \\
\text { related to a large } \\
\text { population was used. Age } \\
\text { and gender variations in } \\
\text { addition to variations } \\
\text { over time were considered } \\
\text { in the study. }\end{array}$ & $\begin{array}{l}\text { Different forms of policies } \\
\text { that may have different } \\
\text { effects, were included to } \\
\text { the policy measure. } \\
\text { Socio-economic factors } \\
\text { were not considered in the } \\
\text { study. }\end{array}$ \\
\hline 2007 & $\begin{array}{l}\text { Terry-McElrath } \\
\text { et al. }\end{array}$ & $\begin{array}{l}\text { To examine the } \\
\text { association between } \\
\text { anti-tobacco advertising } \\
\text { and smoking related } \\
\text { outcomes with respect to } \\
\text { gender and race/ethnicity }\end{array}$ & $\begin{array}{c}\text { Cross } \\
\text { sectional }\end{array}$ & $\begin{array}{l}\text { 8th, 10th, and 12th } \\
\text { grades student data } \\
\text { in 1999-2003 } \\
\text { collected by } \\
\text { Monitoring the } \\
\text { Future study }\end{array}$ & 64,840 & $14-18$ & $\begin{array}{l}\text { Anti-smoking } \\
\text { media } \\
\text { campaigns }\end{array}$ & $\begin{array}{l}\text { Smoking } \\
\text { prevalence }\end{array}$ & $\begin{array}{c}\text { OR: } 0.92 \\
(0.86-0.98)\end{array}$ & $\begin{array}{l}\text { First study to examine the } \\
\text { association between } \\
\text { exposure to anti-tobacco } \\
\text { advertising and smoking } \\
\text { outcomes in } 8 \text { th, 10th, } \\
\text { 12th grades students. } \\
\text { Comparison among males } \\
\text { and females and among } \\
\text { different racial/ethnic } \\
\text { groups was performed. }\end{array}$ & $\begin{array}{l}\text { Hispanics were included } \\
\text { in the study population. } \\
\text { However, } \\
\text { Spanish-language TV } \\
\text { channels were not } \\
\text { included. }\end{array}$ \\
\hline
\end{tabular}




\subsection{Pooled Analysis}

The overall pooled effect size (ES) of the five studies yielded an OR $=1.137$ (C.I. $=0.976-1.298$ and $\mathrm{I}^{2}=85.6 \%$ ). Subgroup analysis by study design revealed a significant pooled estimate $\mathrm{OR}=1.260$ (C.I. $=1.130-1.400)$ for the quasi-experimental study [27] and a non-significant pooled estimate $\mathrm{OR}=1.096$ (C.I. $=0.931-1.260$ ) for the cross-sectional studies $[26,28-30]$. Subgroup analysis by intervention revealed a significant pooled estimate $\mathrm{OR}=1.280$ (C.I. $=1.172-1.389$ and $\mathrm{I}^{2}=0 \%$ ) for studies using legislative smoking bans [26-28,30] and a non-significant pooled estimate $\mathrm{OR}=1.137$ (C.I. $=0.976-1.298$ and $\mathrm{I}^{2}=87.5 \%$ ) for studies using anti-tobacco media campaigns [26,29] (Figure 2).

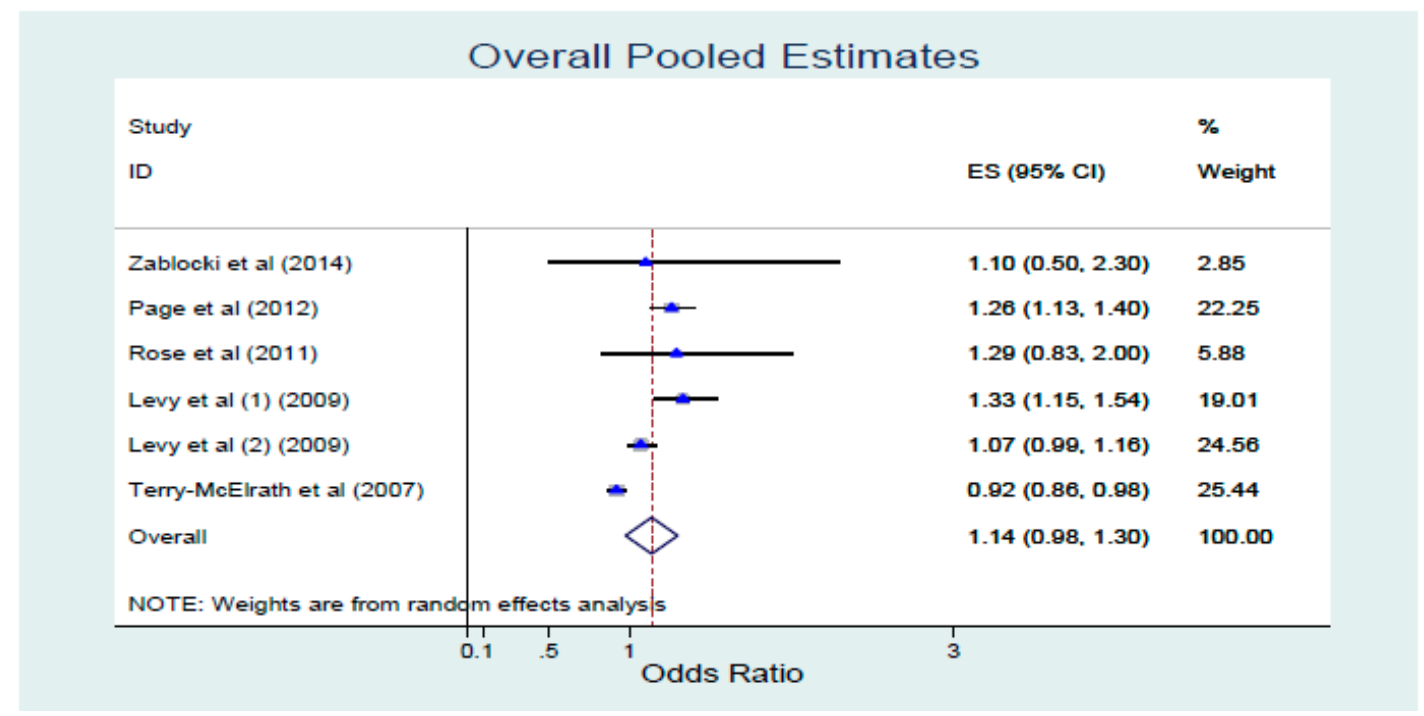

Figure 2. Overall pooled estimates.

\subsection{Risk of Bias}

All five studies were reviewed for risk of bias by using a modified Newcastle Ottawa Scale (NOS) [26-30]. This NOS scale includes three components and eight items: (1) selection of study groups (four items); (2) comparability of the groups (one item); and the (3) ascertainment of the outcomes of interest (three items) [31]. The quality of each study was determined by assigning it to one of three subgroups: (1) good ( $\geq$ two stars for selection of study groups, one star for comparability of the groups, and three stars for ascertainment of the outcomes of interest components); (2) fair (one star for selection of study groups and two stars for ascertainment of the outcomes of interest components); or (3) poor ( 0 stars for selection of study groups, 0 stars for comparability of the groups, and $\leq$ one star for ascertainment of the outcomes of interest components). Risk of bias was designated as: low, if there was good quality in all components; unclear/moderate, if there was fair quality in one or more components without poor quality in any components; or high, if there was poor quality in any one of the components. The four cross-sectional studies were found to have an overall moderate risk of bias, whereas the quasi-experimental study had a low risk of bias (Table 2). 
Table 2. Risk of bias assessment using modified Newcastle Ottawa Scales (NOSs).

\begin{tabular}{|c|c|c|c|c|c|c|c|c|c|c|c|c|}
\hline \multicolumn{2}{|r|}{$\begin{array}{c}\text { NOS. } \\
\text { Cross Sectional }\end{array}$} & \multicolumn{4}{|c|}{ Selection } & \multicolumn{3}{|c|}{ Comparability } & \multicolumn{3}{|c|}{ Outcome } & \multirow[t]{2}{*}{ Risk of Bias } \\
\hline Year & Author & Representativeness & $\begin{array}{l}\text { Ascertainment } \\
\text { of Exposure }\end{array}$ & $\begin{array}{l}\text { Outcome } \\
\text { at start }\end{array}$ & Rating & $\begin{array}{l}\text { Controls } \\
\text { for Gender }\end{array}$ & $\begin{array}{l}\text { Controls } \\
\text { for covariates }\end{array}$ & Rating & $\begin{array}{l}\text { Assessment } \\
\text { of outcome }\end{array}$ & $\begin{array}{c}\text { Completeness } \\
\text { of outcome }\end{array}$ & Rating & \\
\hline 2014 & Zablocki et al. & 1 & 0 & 1 & Good & 1 & 1 & Good & 0 & 1 & Fair & Moderate \\
\hline 2011 & Rose A et al. & 1 & 1 & 1 & Good & 1 & 1 & Good & 0 & 1 & Fair & Moderate \\
\hline 2009 & Levy et al. & 1 & 1 & 1 & Good & 1 & 1 & Good & 0 & 1 & Fair & Moderate \\
\hline 2007 & Terry-McElrath et al. & 1 & 1 & 1 & Good & 1 & 1 & Good & 0 & 1 & Fair & Moderate \\
\hline \multicolumn{2}{|c|}{$\begin{array}{c}\text { NOS } \\
\text { Quasi Experimental }\end{array}$} & \multicolumn{4}{|c|}{ Selection } & \multicolumn{3}{|c|}{ Comparability } & \multicolumn{3}{|c|}{ Outcome } & Risk of bias \\
\hline Year & Author & Representativeness & $\begin{array}{c}\text { Ascertainment } \\
\text { of Exposure }\end{array}$ & $\begin{array}{l}\text { Outcome } \\
\text { at start }\end{array}$ & Rating & $\begin{array}{l}\text { Controls } \\
\text { for Gender }\end{array}$ & $\begin{array}{c}\text { Controls } \\
\text { for covariate }\end{array}$ & Rating & $\begin{array}{l}\text { Assessment } \\
\text { of outcome }\end{array}$ & $\begin{array}{c}\text { Completeness } \\
\text { of outcome }\end{array}$ & Rating & \\
\hline 2012 & Page et al. & 1 & 1 & 1 & Good & 1 & 1 & Good & 0 & 1 & Good & Low \\
\hline
\end{tabular}




\section{Discussion}

Overall, we found that the odds of smoking, though not statistically significant, were reduced by $14 \%$. However, with a stratified pooled analysis by the type of intervention, we found that the odds of achieving smoking reduction among women with the implementation of legislative smoking bans were significantly higher by $28 \%$. Similarly, several studies in the scientific literature corroborate our findings [19,32-34]. It is important to note that much of the global progress made in reducing the prevalence of smoking can be specifically attributed to the efficacy of legislative smoking bans [35-37]. Smoke-free policies banning smoking in public places and workplaces are known to be the most effective measures. Such policies are shown to help denormalize tobacco use [38], reduce smoking prevalence [39], limit exposure to smoke [40] and mitigate negative health outcomes [41].

Our subgroup analysis found that anti-tobacco media campaigns had no statistically significant effect on smoking among women in the US. The pooled odds of smoking due to the implementation of anti-tobacco media campaign among women increased by $1 \%$. There are several plausible explanations for this finding. We posit this may be a reflection of the broad and non-gender-specific messaging of the majority of anti-tobacco campaigns. Additionally, it has been suggested that the effectiveness of media campaigns may be lessened among women because they watch fewer hours of television, when compared to men, and are, therefore, less likely to be exposed to the televised anti-smoking messages [29]. Our findings contradict the evidence reported by several studies, which show anti-tobacco media campaigns to be a useful tool in the reduction of smoking rates [19,37,42-44]. However, it is important to note that the reduction rates reported in the literature were obtained from generalized populations and not specifically for females.

Despite increased global awareness and numerous interventions on this important public health front, smoking rates among women continue to increase dramatically [45-47]. This development is concerning and may be in part attributed to changes in the marketing approach employed by the tobacco industry, as a greater focus is now placed on the use of new social media platforms that lack strict regulatory controls [48,49]. Additionally, the tobacco industry expertly uses various gender-based advertising techniques to glamorize smoking in pop culture, as evidenced in many popular movies, music videos and fashion shows [50,51]. These venues are used as social cues to depict female characters as cool, independent, adventurous and edgy and therefore, strongly appeal to a wide range of young females [52]. A recent report found that young people are exposed to an astounding 14.9 billion tobacco impressions in youth related films annually and that the overall number of tobacco incidents within US movies has increased by $72 \%$ from 2010 to 2018 [45]. This is an important development as the US Surgeon General found a causal link between exposure to these types of images and smoking initiation, especially among young women [53].

\subsection{Strengths and Limitations}

The present study is one of a few to examine the impact and effectiveness of policy measures (i.e., legislative smoking bans and anti-tobacco media campaigns) on smoking reduction specifically among women in the US. By pooling the various effect estimates, we were able to increase the sample size and thus, the power of the study to assess the desired effect. Our study provides significant evidence that can be used as a reference point for future research. Despite these notable strengths, our study is not without its limitations. First, there are only a small number of studies that use quantifiable data and a sound research methodology to study this topic, which limited our meta-analysis. Second, there was a marked heterogeneity among the included studies and therefore, the pooled results should be interpreted with some degree of caution. Third, the included studies obtained information through follow up surveys but did not account for loss to follow up and its resultant bias. Finally, the majority of the studies were cross-sectional in nature and thus, reported on associations but cannot infer causation. 


\subsection{Implications for Policy and/or Practice}

Successfully thwarting and/or reversing increases in tobacco use among women will lead to improved quality of life, positive health outcomes and major disease prevention opportunities. Our findings provide significant implications for interventions aimed at reducing smoking among women in the US. Legislative smoking bans were found to be associated with a reduction in the smoking rates among women, while anti-tobacco media campaigns did not. Legislative smoking bans need to be promoted, enforced and further strengthened. Anti-tobacco media campaigns need to be thoughtfully reviewed and revised and specifically tailored so as to effectively counter the tobacco industry's targeting of women and expose its deliberate efforts to link smoking with women's issues of independence, rights, status and progress in society [54].

\section{Conclusions}

The complex and critical connection between smoking and women's health needs to be widely acknowledged and fully elucidated, along with a gendered-based analysis of tobacco use, advertising and legislation. This meta-analysis sought to determine the impact and effectiveness of counter tobacco marketing and legislative smoking bans in the reduction of smoking rates among women. This topic requires urgent attention, comprehensive policies and further high-quality research (e.g., using control groups for comparison analysis, pre- and post-ban data and robust biochemically measured outcomes), with large sample sizes and longer follow up periods (six months or longer) to determine the most effective strategies for implementation and enforcement of smoking bans to prevent and/or reduce the extent of the tobacco epidemic among women in the US and across the world.

Author Contributions: Conceptualization, Y.B. and J.M.; data Curation and formal analysis, L.K. and C.N.; methodology, supervision and validation, Y.B. and J.M.; writing-original draft, all authors; final review and editing, Y.B., J.M. and L.K. All authors have read and agreed to the published version of the manuscript.

Acknowledgments: The corresponding author acknowledges and thanks the Faculty of Health Studies, Brandon University.

Conflicts of Interest: The authors report no conflicts of interest in this work.

\section{References}

1. United States Surgeon General's Advisory Committee on Smoking and Health; United States Public Health Service; Office of the Surgeon General Smoking and Health. Report of the Advisory Committee to the Surgeon General of the Public Health Service; Office of the Surgeon General: Washington, DC, USA, 1964.

2. Public Health Agency of Canada. Smokers, by Sex, Provinces and Territories-Open Government Portal. Available online: https://open.canada.ca/data/en/dataset/d5cbc45b-ae7b-49cd-8456-8b5a387ff059 (accessed on 10 June 2018).

3. Jamal, A.; Homa, D.M.; O'Connor, E.; Babb, S.D.; Caraballo, R.S.; Singh, T.; Hu, S.S.; King, B.A. Current cigarette smoking among adults-United States, 2005-2014. MMWR Morb. Mortal. Wkly. Rep. 2015, 64, 1233-1240. [CrossRef] [PubMed]

4. Mathers, C.D.; Loncar, D. Projections of global mortality and burden of disease from 2002 to 2030. PLoS Med. 2006, 3, e442. [CrossRef]

5. Reid, J.L.; Hammond, D.; Burkhalter, R.; Ahmed, R. Tobacco Use in Canada: Patterns and Trends; Propel Centre for Population Health Impact; University of Waterloo: Waterloo, ON, Canada, 2012.

6. U.S. Department of Health and Human Services. The Health Consequences of Smoking - 50 Years of Progress: A Report of the Surgeon General; U.S. Department of Health and Human Services, Centers for Disease Control and Prevention, National Center for Chronic Disease Prevention and Health Promotion, Office on Smoking and Health: Atlanta, GA, USA, 2014.

7. Novotny, T.E.; Giovino, G.A. Tobacco Use. In Chronic Disease Epidemiology and Control; Brownson, R.C., Remington, P.L., Davis, J.R., Eds.; American Public Health Association: Washington, DC, USA, 1998; pp. 117-148. 
8. Office on Smoking and Health (US). Women and Smoking: A Report of the Surgeon General; Centers for Disease Control and Prevention (US): Atlanta, GA, USA, 2001.

9. Huxley, R.R.; Woodward, M. Cigarette smoking as a risk factor for coronary heart disease in women compared with men: A systematic review and meta-analysis of prospective cohort studies. Lancet Lond. Engl. 2011, 378, 1297-1305. [CrossRef]

10. Bloch, M.; Althabe, F.; Onyamboko, M.; Kaseba-Sata, C.; Castilla, E.E.; Freire, S.; Garces, A.L.; Parida, S.; Goudar,S.S.; Kadir, M.M.; et al. Tobacco use and secondhand smoke exposure during pregnancy: An investigative survey of women in 9 developing nations. Am. J. Public Health 2008, 98, 1833-1840. [CrossRef]

11. U.S. Department of Health and Human Services. The Health Benefits of Smoking Cessation: A Report of the Surgeon General; U.S. Department of Health and Human Services, Public Health Service, Centers for Disease Control, Center for Chronic Disease Prevention and Health Promotion, Office on Smoking and Health: Washington, DC, USA, 1990.

12. Amos, A.; Greaves, L.; Nichter, M.; Bloch, M. Women and tobacco: A call for including gender in tobacco control research, policy and practice. Tob. Control 2012, 21, 236-243. [CrossRef]

13. Brown-Johnson, C.G.; England, L.J.; Glantz, S.A.; Ling, P.M. Tobacco industry marketing to low socioeconomic status women in the U.S.A. Tob. Control 2014, 23, e139-e146. [CrossRef]

14. Toll, B.A.; Ling, P.M. The Virginia Slims identity crisis: An inside look at tobacco industry marketing to women. Tob. Control 2005, 14, 172-180. [CrossRef]

15. Marmot, M. Smoking and inequalities. Lancet Lond. 2006, 368, 341-342. [CrossRef]

16. Lorenc, T.; Petticrew, M.; Welch, V.; Tugwell, P. What types of interventions generate inequalities? Evidence from systematic reviews. J. Epidemiol. Commun. Health 2013, 67, 190-193. [CrossRef] [PubMed]

17. Hill, S.; Amos, A.; Clifford, D.; Platt, S. Impact of tobacco control interventions on socioeconomic inequalities in smoking: Review of the evidence. Tob. Control 2014, 23, e89-e97. [CrossRef] [PubMed]

18. World Health Organization. WHO Framework Convention on Tobacco Control 2003; World Health Organization: Geneva, Switzerland, 2003.

19. Hoffman, S.J.; Tan, C. Overview of systematic reviews on the health-related effects of government tobacco control policies. BMC Public Health 2015, 15, 744. [CrossRef] [PubMed]

20. Bala, M.M.; Strzeszynski, L.; Topor-Madry, R.; Cahill, K. Mass media interventions for smoking cessation in adults. Cochrane Database Syst. Rev. 2013, CD004704. [CrossRef] [PubMed]

21. de Kleijn, M.J.J.; Farmer, M.M.; Booth, M.; Motala, A.; Smith, A.; Sherman, S.; Assendelft, W.J.J.; Shekelle, P. Systematic review of school-based interventions to prevent smoking for girls. Syst. Rev. 2015, 4, 109. [CrossRef] [PubMed]

22. Schoonjans, F. MedCalc Statistical Software. Available online: https://www.medcalc.org/ (accessed on 7 June 2018).

23. Hedges, L.V.; Vevea, J.L. Fixed and random effects models in meta-analysis. Psychol. Methods 1998, 3, 486-504. [CrossRef]

24. Higgins, J.P.T.; Thompson, S.G. Quantifying heterogeneity in a meta-analysis. Stat. Med. 2002, 21, 1539-1558. [CrossRef]

25. Tobias, A. Assessing the influence of a single study in the meta-anyalysis estimate. Stata Tech. Bull. 1999, 8, 47.

26. Levy, D.T.; Tauras, J.A.; Gerlowski, D.A.; Bergman, J.; Compton, C. The Decision to Smoke and the Frequency of Smoking by Age and Gender. J. Appl. Econ. Policy Highl. Heights 2009, 28, 1-19.

27. Page, R.L.; Slejko, J.F.; Libby, A.M. A Citywide Smoking Ban Reduced Maternal Smoking and Risk for Preterm Births: A Colorado Natural Experiment. J. Womens Health 2012, 21, 621-627. [CrossRef]

28. Rose, A.; Fagan, P.; Lawrence, D.; Hart, A.; Shavers, V.L.; Gibson, J.T.; Rose, A.; Fagan, P.; Lawrence, D.; Hart, A.J.; et al. The role of worksite and home smoking bans in smoking cessation among U.S. employed adult female smokers. Am. J. Health Promot. 2011, 26, 26-36. [CrossRef]

29. Terry-McElrath, Y.M.; Wakefield, M.A.; Emery, S.; Saffer, H.; Szczypka, G.; O’Malley, P.M.; Johnston, L.D.; Chaloupka, F.J.; Flay, B.R. State anti-tobacco advertising and smoking outcomes by gender and race/ethnicity. Ethn. Health 2007, 12, 339-362. [CrossRef]

30. Zablocki, R.W.; Edland, S.D.; Myers, M.G.; Strong, D.R.; Hofstetter, C.R.; Al-Delaimy, W.K. Smoking ban policies and their influence on smoking behaviors among current California smokers: A population-based study. Prev. Med. 2014, 59, 73-78. [CrossRef] [PubMed] 
31. Wells, G.; Shea, B.; O'Connell, D.; Peterson, J.; Welch, V.; Losos, M.; Tugwell, P. The Newcastle-Ottawa Scale (NOS) for Assessing the Quality of Nonrandomised Studies in Meta-Analyses; Ottawa Health Research Institute: Ottawa, ON, Canada, 1999.

32. Naiman, A.; Glazier, R.H.; Moineddin, R. Association of anti-smoking legislation with rates of hospital admission for cardiovascular and respiratory conditions. CMAJ Can. Med. Assoc. J. J. Assoc. Med. Can. 2010, 182, 761-767. [CrossRef] [PubMed]

33. Callinan, J.E.; Clarke, A.; Doherty, K.; Kelleher, C. Legislative smoking bans for reducing secondhand smoke exposure, smoking prevalence and tobacco consumption. Cochrane Database Syst. Rev. 2010, CD005992. [CrossRef]

34. Evans, W.N.; Farrelly, M.C.; Montgomery, E. Do Workplace Smoking Bans Reduce Smoking? Am. Econ. Rev. 1999, 89, 728-747. [CrossRef]

35. WHO. WHO Report on the Global Tobacco Epidemic 2017, Monitoring Tobacco Use and Prevention Policies; World Health Organization: Geneva, Switzerland, 2017.

36. Crotty, J.; Driffield, N.; Jones, C. Regulation as Country-Specific (Dis-) Advantage: Smoking Bans and the Location of Foreign Direct Investment in the Tobacco Industry. Br. J. Manag. 2016, 27, 464-478. [CrossRef]

37. Durkin, S.J.; Biener, L.; Wakefield, M.A. Effects of Different Types of Antismoking Ads on Reducing Disparities in Smoking Cessation Among Socioeconomic Subgroups. Am. J. Public Health 2009, 99, 2217-2223. [CrossRef]

38. Hamilton, W.L.; Biener, L.; Brennan, R.T. Do local tobacco regulations influence perceived smoking norms? Evidence from adult and youth surveys in Massachusetts. Health Educ Res. 2008, 23, 709-722. [CrossRef]

39. Hafez, A.Y.; Gonzalez, M.; Kulik, M.C.; Vijayaraghavan, M.; Glantz, S.A. Uneven Access to Smoke-Free Laws and Policies and Its Effect on Health Equity in the United States: 2000-2019. Am. J. Public Health 2019, 109, 1568-1575. [CrossRef]

40. Frazer, K.; Callinan, J.E.; McHugh, J.; van Baarsel, S.; Clarke, A.; Doherty, K.; Kelleher, C. Legislative smoking bans for reducing harms from secondhand smoke exposure, smoking prevalence and tobacco consumption. Cochrane Database Syst. Rev. 2016, 2, CD005992. [CrossRef]

41. Mackay, D.; Haw, S.; Ayres, J.G.; Fischbacher, C.; Pell, J.P. Smoke-free legislation and hospitalizations for childhood asthma. N. Engl. J. Med. 2010, 363, 1139-1145. [CrossRef]

42. Parkinson, C.M.; Hammond, D.; Fong, G.T.; Borland, R.; Omar, M.; Sirirassamee, B.; Awang, R.; Driezen, P.; Thompson, M. Smoking beliefs and behavior among youth in Malaysia and Thailand. Am. J. Health Behav. 2009, 33, 366-375. [CrossRef] [PubMed]

43. Hyland, A.; Wakefield, M.; Higbee, C.; Szczypka, G.; Cummings, K.M. Anti-tobacco television advertising and indicators of smoking cessation in adults: A cohort study. Health Educ. Res. 2006, 21, 296-302. [CrossRef] [PubMed]

44. Warner, K.E. The effects of the anti-smoking campaign on cigarette consumption. Am. J. Public Health 1977, 67, 645-650. [CrossRef] [PubMed]

45. Janz, T. Current Smoking Trends. Available online: https://www150.statcan.gc.ca/n1/pub/82-624-x/2012001/ article/11676-eng.htm (accessed on 4 June 2018).

46. Goel, S.; Tripathy, J.P.; Singh, R.J.; Lal, P. Smoking trends among women in India: Analysis of nationally representative surveys (1993-2009). South Asian J. Cancer 2014, 3, 200-202. [CrossRef]

47. Li, X.; Holahan, C.K.; Holahan, C.J. Sociodemographic and Psychological Characteristics of Very Light Smoking Among Women in Emerging Adulthood, National Survey of Drug Use and Health, 2011. Prev. Chronic. Dis. 2015, 12. [CrossRef]

48. Cavazos-Rehg, P.A.; Krauss, M.J.; Spitznagel, E.L.; Grucza, R.A.; Bierut, L.J. Hazards of new media: youth's exposure to tobacco Ads/promotions. Nicotine Tob. Res. Off. J. Soc. Res. Nicotine Tob. 2014, 16, 437-444. [CrossRef]

49. Liang, Y.; Zheng, X.; Zeng, D.D.; Zhou, X.; Leischow, S.J.; Chung, W. Exploring how the tobacco industry presents and promotes itself in social media. J. Med. Internet Res. 2015, 17, e24. [CrossRef]

50. Kaleta, D.; Usidame, B.; Polanska, K. Tobacco Advertisements Targeted on Women: Creating an Awareness Among Women. Cent. Eur. J. Public Health Prague 2011, 19, 73-78. [CrossRef]

51. Tynan, M.A.; Polansky, J.R.; Titus, K.; Atayeva, R.; Glantz, S.A. Tobacco Use in Top-Grossing Movies-United States, 2010-2016. MMWR Morb. Mortal. Wkly. Rep. 2017, 66, 681-686. [CrossRef]

52. Anderson, S.J.; Glantz, S.A.; Ling, P.M. Emotions for sale: Cigarette advertising and women's psychosocial needs. Tob. Control 2005, 14, 127-135. [CrossRef] 
53. U.S. Department of Health and Human Services. Preventing Tobacco Use Among Youth and Young Adults: A Report of the Surgeon General; U.S. Department of Health and Human Services, Public Health Service, Office of the Surgeon General: Rockville, MD, USA, 2012.

54. Gilmore, A.B.; Fooks, G.; Drope, J.; Bialous, S.A.; Jackson, R.R. Exposing and addressing tobacco industry conduct in low-income and middle-income countries. Lancet 2015, 385, 1029-1043. [CrossRef]

(C) 2020 by the authors. Licensee MDPI, Basel, Switzerland. This article is an open access article distributed under the terms and conditions of the Creative Commons Attribution (CC BY) license (http://creativecommons.org/licenses/by/4.0/). 